\title{
Development of a Technology Integration Monitoring System
}

\author{
Miller A.E. ${ }^{*}$ Miller M.A.
}

\author{
Omsk State University F.M. Dostoevsky, Omsk, Russia \\ *Corresponding author. Email: aem55@yandex.ru
}

\begin{abstract}
The article is dedicated to the development of analytical tools for tracking the parameters of technology integration in the production sector. A technology integration monitoring system is developed, which consists of 3 main stages and includes an object, subject, entities, methods and means of the monitoring process of technological integration of industrial organizations. The principles of building a monitoring system are formulated. The developed monitoring system involves the collection and analysis of information about the parameters of technology integration of production entities, selected for observation. An approximate list of the observed parameters of technology integration is given with an indication of the units of measurement and the frequency of collection. Observation as the most important stage of the technology integration monitoring system is proposed to be carried out through the use of such methods of collecting information and processing results as analysis of materials in the free information access, expert survey, questionnaire, statistical accounting, calculation method. The results of the technology integration assessment, being determined within the framework of the corresponding stage of the monitoring system, act as the basis for the implementation of regulatory measures to improve the regulatory and organizational and managerial conditions for the participation of industrial enterprises in the process of integrating technological solutions by the technology integration entities.
\end{abstract}

Keywords: technology integration, monitoring, monitoring system, observed parameters, industrial

enterprises

\section{INTRODUCTION}

The development of the world economy at the present stage objectively expands the range and depth of various business interactions of business entities, including in the production sector of the economy. The desire to create modern production with a high technological component, to increase its competitiveness in the market contributes to an increase in the frequency of mutually beneficial contacts with environmental entities, and the need to monitor changing economic processes and comply with emerging technological trends pushes the organization to solve the problem of improving their quality.

In the conditions of the formation of Industry 4.0., based on the digitalization of production systems, in the world economic system, the need for the development of various formats of technology integration of industrial enterprises is being updated. This kind of industrial and economic integration, implemented also through intra-industry and inter-industry cooperation, is designed to combine the technical and technological capabilities of organizations, integrate into productive production chains, supplement own technological process with the missing technologies and competencies, to carry out joint development and launch of new products. It should also be noted, that with the formation and active development of the digital economy, modern technology integration is becoming more and more practice, arising from the emergence and spread of solutions, that are born at the intersection of technologies.

With the activation of technology integration processes in industrial production, the need for the development of analytical tools to track the qualitative and quantitative characteristics of this process and the implementation, if necessary, of appropriate corrective and regulatory influences, is becoming actual. The creation of a system for tracking technology integration practices, that reveal such modern trends of technological development of the industry as a change in the content of the production process, the development of information and telecommunication technologies in production and the reduction of the period of technological changes, allows to better understand the emerging vectors of technical and technological interaction, to generalize the best practices of technology integration and formulate leading approaches in this area to increase results of modern production.

In this regard, the purpose of this article is to develop a system for monitoring the technology integration of industrial enterprises. 
2. methods of logic and abstraction - creating a conceptual scheme of a technology integration monitoring system;

3. description method - determination of observable parameters in the framework of monitoring of technology integration.

\section{RESEARCH RESULTS}

As part of the development of a technology integration monitoring system, the priority is to clarify the terminology. As a result, the author's position on the key concepts of the considered topic is as follows.

First, according to the authors' point of view, stated in one of the previous publications, technology integration is a direction of system technologization, including a set of mechanisms, tools and methods for practical implementation at industrial enterprises [17].

Second, under the monitoring of technology integration, it is proposed to understand the process of tracking changes in the technical and technological and organizational parameters of the integration process, in which the industrial enterprise and its integration partners (another industrial enterprise, information and communication service organization, etc.) participate.

Third, according to the authors' of this article point of view, the technology integration monitoring system is a set of related monitoring elements, involved in monitoring and assessing the parameters of the integration process, the results of which are the basis for the implementation of regulatory effects on the monitoring object (industrial enterprises).

The general scheme of the technology integration monitoring system is presented in fig. 1 .

According to scheme at fig. 1, the technology integration monitoring system at industrial enterprises consists of 3 stages.

At the first stage of "Observation", the process of collecting and recording data of changes at the monitoring object - industrial enterprises, involved in technology integration. 


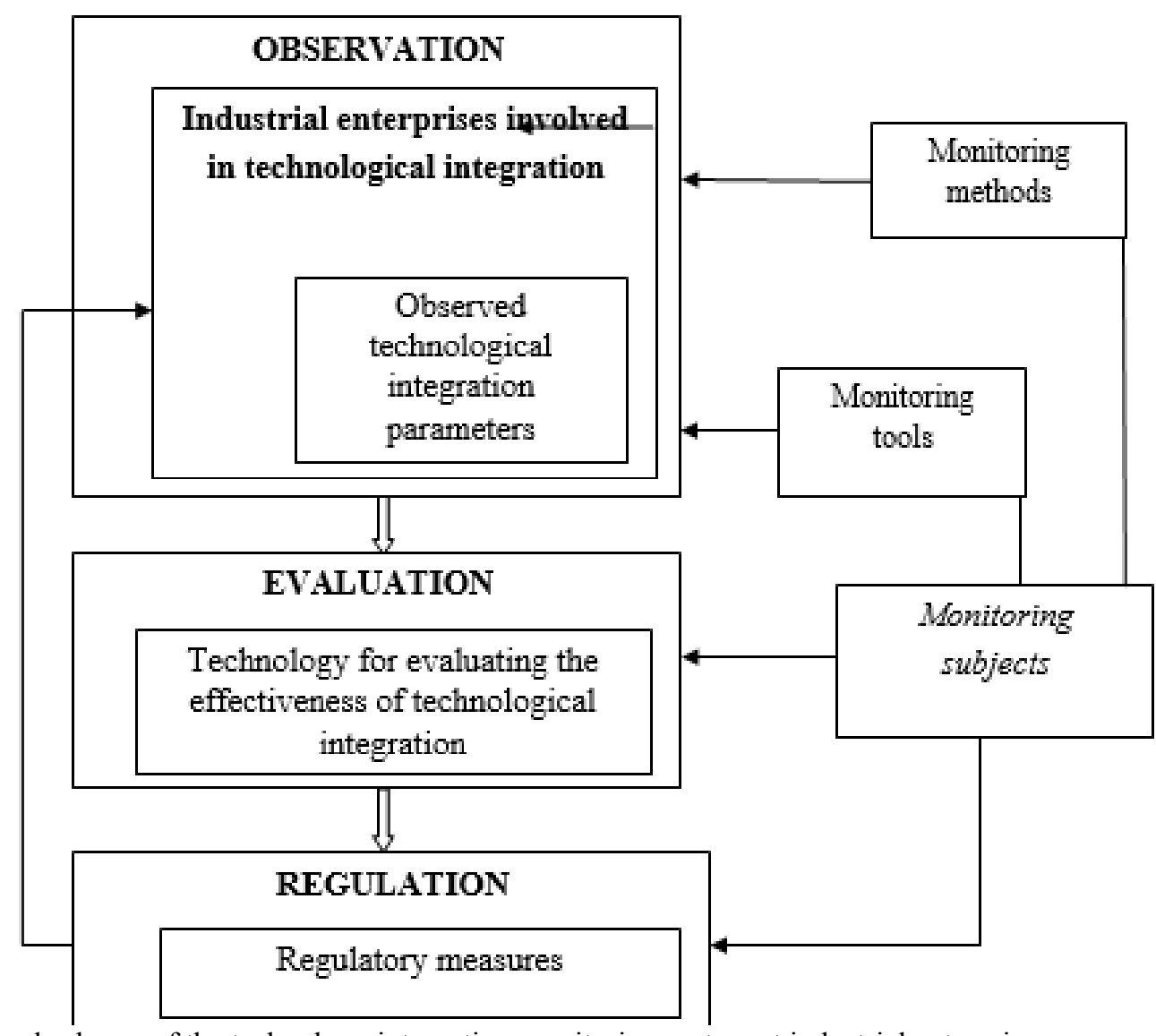

Figure 1 General scheme of the technology integration monitoring system at industrial enterprises

Relatively, the observable technical and technological and organizational parameters of integration are the subject of monitoring.

Approximate options of the observed parameters with the units of measurement and the recommended frequency of data collection are given in table 1 .

The first monitoring stage is implemented by those monitoring entities, which are responsible for the collection and processing of monitoring data, as well as for the technical maintenance of the stage. Moreover, these entities use 2 types of tools: monitoring tools and methods. Monitoring tools include:

1. regulations and procedures, which are the legal and organizational basis for entities to monitor the process of observing changes in the parameters of technology integration;

4. software products for the collection and processing of monitoring data, which help to simplify the processes of data accumulation, accelerate their interpretation and create convenient forms for their subsequent presentation.
The methods of collecting information and processing the results can be different, while multi-sided monitoring allows to perform:

- method of analysis of materials (in free information access);

- $\quad$ expert survey;

- $\quad$ questioning;

- $\quad$ statistical accounting;

- calculation method.

The second monitoring stage - "Assessment" - involves the analysis of the results of technology integration at the monitoring object. Assessment of technology integration is carried out either by the same monitoring entities, that implemented the first stage, or others with the appropriate competencies. As a tools at this stage, it is proposed to use the technology for assessment of the productivity of technology integration, developed and presented by the authors in one of the previous publications on this topic and including production and technological productivity, 
organizational productivity and economic productivity of integration processes [17].

The third stage of monitoring is "Regulation". Its objective: on the basis of the report analytics on technology integration from the previous stage, determine the need to develop and implement regulatory measures, aimed at improving organizational and procedural, economic and other possible conditions and requirements to increase the productivity of technology integration practices at industrial enterprises in future time periods. At this stage, the monitoring entities act as the so-called monitoring system management authorities, which may include (depending on the extent of monitoring) specialized executive authorities or large industrial enterprises. Thus, it is an important justification for the need for relevant decisions on organizational and economic issues of technological development of industrial enterprises.

Table 1 Observed parameters of monitoring of technology integration

\begin{tabular}{|c|c|c|c|}
\hline No. & Observed parameters & $\begin{array}{c}\text { Units of } \\
\text { measurement }\end{array}$ & $\begin{array}{l}\text { Frequency of data } \\
\text { collection }\end{array}$ \\
\hline 1. & The number of technology integration practices during the monitoring period & Units & Twice a year \\
\hline 2. & $\begin{array}{l}\text { The number of technology integration practices by industry sectors (sub- } \\
\text { sectors) }\end{array}$ & Units & Twice a year \\
\hline 3. & $\begin{array}{l}\text { The structure of industrial enterprises - monitoring objects by size (large, medium, } \\
\text { small) }\end{array}$ & $\%$ & Twice a year \\
\hline 4. & $\begin{array}{l}\text { The number of technology integration practices in the directions of integration } \\
\text { (highly specialized technological operations, the creation of new materials, the } \\
\text { industrial Internet of things, industrial robotics, additive technologies, big data, } \\
\text { digital design and modeling of parts and products, etc.) }\end{array}$ & Units & Twice a year \\
\hline 5 & Dynamics of technology integration practices by the directions of integration & $\%$ & Twice a year \\
\hline 6. & The structure of technology integration practices by the directions of integration & $\%$ & Twice a year \\
\hline 7. & $\begin{array}{l}\text { The structure of the types of partners of an industrial enterprise for technology } \\
\text { integration (another industrial enterprise, information and communication service } \\
\text { organization, research organization, university, etc.). }\end{array}$ & $\%$ & Twice a year \\
\hline 8. & $\begin{array}{l}\text { The structure of technology integration practices according to the national status of } \\
\text { business entities, involved in the integration, which are technology rights holders } \\
\text { (national organization - national organization; national organization - foreign } \\
\text { organization (including transnational corporation)) }\end{array}$ & $\%$ & Twice a year \\
\hline 9. & $\begin{array}{l}\text { The list of typical difficulties, that enterprises face in the process of technology } \\
\text { integration (qualitative parameter: list of the most common difficulties) }\end{array}$ & list & once a year \\
\hline 10. & $\begin{array}{l}\text { The structure of typical difficulties during technology integration, by type } \\
\text { (technical and technological, organizational, economic) }\end{array}$ & $\%$ & once a year \\
\hline 11. & $\begin{array}{l}\text { The share of outside experts, involved in the implementation of technology } \\
\text { integration, who are not employees of integred organizations, of the total number } \\
\text { of employees, participating in technology integration activities }\end{array}$ & $\%$ & Twice a year \\
\hline 12. & $\begin{array}{l}\text { The level of changes to related production processes at the monitoring object in the } \\
\text { process of technology integration (qualitative parameter: level scale (high, } \\
\text { medium, low)) }\end{array}$ & $\begin{array}{l}\text { Level value } \\
\text { from } \\
\text { suggested } \\
\text { options }\end{array}$ & once a year \\
\hline
\end{tabular}

\section{DISCUSSION OF RESULTS}

The template version of the proposed monitoring system makes it possible to adapt it to own specifics and the assessment objectives, facing the governing authorities of the monitoring system. However, from the point of authors' view, the construction of a monitoring system for a specific monitoring object should be carried out taking into account the following principles:

1. The principle of sufficiency - when monitoring, the minimum necessary number of monitoring procedures should be used, especially involving the distraction of participants in the integration process to measure integration parameters.

2. The principle of information completeness the totality of the collected data on the parameters of technology integration should give a complete picture of the state of the integration process during the monitoring "cross-section". 
3. The principle of objectivity - the monitoring entities should be relatively independent and free in the processes of observation, assessment and regulation of technology integration in order to form objective monitoring results.

The proposed list of observed parameters of technology integration is not exhaustive and solely correct, but serves as a guideline for updating this list for the selected monitoring object. It is proposed, that the quality parameters 9 and 12 are determined by an expert group, including both representatives of organizations, involved in technology integration and external experts, involved in the integration and formed before the start of monitoring. In addition, in the framework of using the selected monitoring methods, it is necessary to provide a description of the observed parameters, develop a procedure for processing the results of observations and the form of their presentation, as well as, if necessary: determine the values of the observed parameters, accepted as normal, permissible and critical, select the observation mode (continuous, periodic), set the accuracy of measurements of the observed parameters.

\section{CONCLUSION}

Thus, in the article on the basis of actualization of the need to introduce additional tools for the analysis of technology integration, a technology integration monitoring system is developed and described. Using a monitoring system allows to observe and asses the practices of implementation of technology integration by industrial enterprises, as well as to develop and conduct regulatory control, aimed at increasing the return from technology integration in industrial production, searching and using mutually beneficial cooperation formats in the field of compatibility of technological solutions and production processes, which contributes to increased productivity in the industrial sector of economy.

Technology integration monitoring is considered as the most important element in the analysis and regulation of the development conditions of individual industrial enterprises, industrial complexes and industries. The monitoring system should become a permanent component of short- and medium-term planning and development of industrial development strategies at the micro, sectoral and national levels.

\section{ACKNOWLEDGMENT}

The study was carried out with the financial support of the RFBR as a part of the scientific project No. 19-010-00081 (The reported study was funded by RFBR according to the research project No. 19-010-00081).

\section{REFERENCES}

[1] Reinert E.S. How rich countries got rich and why poor countries stay poor. - Moscow, HSE publ., 2017. $384 \mathrm{p}$.

[2] Shvab K. Chetvertaya promyshlennaya revolyutsiya. - M.: Izd-vo «Eksmo», 2018. - $288 \mathrm{~s}$.

[3] Shvab K., Devis N. Tekhnologii Chetvertoy promyshlennoy revolyutsii. - M.: Izd-vo «Eksmo», 2018. $-320 \mathrm{~s}$.

[4] Bodrunov S.D. The Coming of New Industrial Society: Reloaded. - Saint-Petersburg, INID n.a. S.Y. Vitte publ., 2016. - 358 p.

[5] Razmanova, S.V., Machula, I.A. Razvitiye otechestvennogo i mirovogo neftegazokhimicheskogo kompleksa / S.V. Razmanova, I.A. Machula // Neftepererabotka i neftekhimiya. - 2016. - №1. - S. 29.

[6] Khusainov, B.D., Shelomentsev, A.G., Doroshenko, S.V. Sovremennyye integratsionnyye obrazovaniya: komparativnyy analiz faktorov ekonomicheskogo rosta / B.D. Khusainov, A.G. Shelomentsev, S.V. Doroshenko // Ekonomika regiona. - 2015. - №1. S.156-169.-S.167 // DOI 10.17059/2015-1-14.

[7] Il'in, M.S. Finansovo-promyshlennaya integratsiya i korporativnyye struktury: mirovoy opyt i realii Rossii / M.S.Il'in, A.G.Tikhonov. - M.: Al'pina Pablisher, 2003. $-286 \mathrm{~s}$.

[8] Gerasina, YU.A., Larionov, I.K. Sushchnostnyye parametry integrirovannoy sistemy khozyaystvovaniya / YU.A. Gerasina, I.K. Larionov // Ekonomikoyuridicheskiy zhurnal «Biznes v zakone». - 2012. - №5. - S.103.

[9] Tsvetkov, V.A. Korporativnyy biznes: teoriya i praktika / V.A. Tsvetkov - SPb.: Nestor-Istoriya, 2011. $-504 \mathrm{~s}$.

[10] Boschma R., Hartog M. Merger and Acquisition Activity as Driver of Spatial / R. Boschma, M. Hartog / Clustering: The Spatial Evolution of the Dutch Banking Industry, 1850-1993. // Economic Geography - 2014.- 
Vol. 90. - Iss.3. -pp. 247-266. - R. 257. - DOI 10.1111/ecge. 12054

[11] Boschma, R., Fornahl, D. Cluster Evolution and a Roadmap for Future Research / R. Boschma, D. Fornahl // Regional Studies. - 2011. - Vol.45. - Iss.10. - pp. 1295-1298. - DOI 10.1080/00343404.2011.633253

[12] Dahmen, Andreas dr. Strategische Einflussfaktoren von M\&A-Transaktionen (Doctoral (PhD) thesis) -West-Hungarian University, Doctoral School Istvan Szechenyi, Sopron, 2010. - R. 12.

[13] Mil'ner, B.Z. Upravleniye znaniyami v korporatsiyakh / B.Z. Mil'ner, Z.P. Rumyantseva, V.G. Smirnova, A.V. Blinnikova // - Moskva: Delo, 2006. 304 s.

[14] Gomtsyan, S.V. Pravila pogloshcheniya aktsionernykh obshchestv: sravnitel'no-pravovoy analiz: monografiya / S.V. Gomtsyan. - M.: Volters Kluver, 2010. - $320 \mathrm{~s}$.

[15] Ivanov, YU.V. Podsistemy i kharakteristiki organizatsii / YU.V. Ivanov // Upravlyayem predpriyatiyem. - 2011. - №11. - [Elektronnyy resurs]. Rezhim dostupa: http://www.upr.ru/magazine/11.

[16] Davidenko, L.M. Integration Processes on the Basis of State-Private Partnership (Following the Materials of the Republic of Kazakhstan) [Tekst, Elektronnyy resurs] / V.P. Shelomentseva, L.M. Davidenko // World Applied Sciences Journal (WASJ). - 2013. - Vol. 23. - № 2. - RR. 224 - 230. - DOI: 10.5829/idosi.wasj.2013.23.02.23055

[17] Miller A., Miller M. Development of technology for assessing the effectiveness of technological integration // Proceedings of the 1st International Scientific Conference "Modern Management Trends and the Digital Economy - From Regional Development to Global Economic Growth" (MTDE), Advances in Economics, Business and Management Research, ATLANTIS PRESS, Paris, France. - Volume 81, 2019. P. 69-72. 